\title{
Cihannüma
}

Tarih ve Coğrafya Araştırmaları Dergisi

Say1 V/1 - Temmuz 2019, 170-174

\section{Michael B. Barry, Homage to al-Andalus: The Rise and Fall of Islamic Spain, Andalus Press, Dublin, 2016, 256 shf., ISBN: 9780993355417}

Klasik tarihi anlatının dışına çıkan bu eserde Michael B. Barry okuyucuya sadece İslam hâkimiyeti altındaki Endülüs topraklarının değil İber Yarımadası'nın Hristiyan hâkimiyeti altında kalan topraklarının da tarihi, içtimai, dini ve kültürel yönlerini sunmaktadır. Ortaçağ Endülüs tarih ve medeniyeti çerçevesini aşan bu eser İber Yarımadası'nın tarih öncesi devirlerini, İslam hâkimiyetinin sağlanmasıyla yaşanan dönüşüm sürecini, bölgenin İslam hâkimiyeti altındaki devirlerini ve son olarak da Reconquista Hareketi neticesinde Hristiyanların eline geçmesinden sonraki devri anlatılmaktadır.

Giriş ve sekiz ana bölümden oluşan eserde zengin görsel kullanımı dikkat çekmektedir. Bahsedilen konulara göre kitabın içerisine yerleştirilen fotoğraflar ve haritalar okuyucunun muhayyilesinde konunun daha iyi kavranmasina katk1 sağlayacak niteliktedir.

Eserin ilk bölümünde İber Yarımadası'nın coğrafi konumu ve stratejik önemi hakkında malumat verildikten sonra yarımadanın tarih öncesi devirlerden 711 yllındaki İslam fethine kadar olan tarihinden muhtasar olarak bahsedilmektedir. Yarımadadaki ilk insan izlerinden başlayarak burada hüküm süren sırasıyla Fenikeliler, Romalılar, muhtelif Barbar kavimleri ve son olarak da Vizigotlar devrinde yarımadanın siyasi ve içtimai durumu anlatılmaktadır. Bölümün sonlarında Barry Hz. Muhammed riyasetinde İslam devletinin kurulmasina ve daha sonraki Hulefâ-yi Râşidîn devrindeki İslam fetihlerine değinmektedir. Yarımadanın Müslümanlarca fethine kadar olan süreci işleyen yazar bu bölümde okuyucuya Kuzey Afrika'dan Cebelitarlk'a yani Endülüs'ün fethinin gerçekleştiği bölgeye kadar olan İslam fetihlerinin seyri hakkında fikir vermektedir.

İkinci bölümde Barry İspanya’nın Müslümanlarca fethi sırasında Vizigotların içinde bulunduğu durum ve o devirde bölgedeki güç dengelerinden bahsedip Tarif b. Malik liderliğinde bir öncü birliğin Müslümanlar tarafindan yarımadaya akın yaptı̆̆ını belirtmektedir. Ancak yazarın aksine devrin Hristiyan ve Müslüman kaynakları Tarif b. Malik'in bu seferinden bir akından ziyade yarımadanın durumunu öğrenmek için gönderilen keşif seferi olarak bahsettiklerini de hatırlatmamız gerekmektedir. 711 yllında Tarık b. Ziyad'ın yarımadaya ayak basması ve daha sonra onun azatlisi olduğu Emevilerin Mağrib valisi Musa b. Nusayr'ın da sefere dâhil olmasıyla Vizigot hâkimiyetindeki toprakların Müslümanların eline geçişi bu bölümde anlatılmaktadır. Yarımadanın Müslümanların eline geçmesiyle bölgedeki yerel sakinlerle Müslümanlar arasında yapılan anlaşmalardan bahseden Barry bu anlaşmalara örnek olarak Musa b. Nusayr'ın oğlu ve Emeviler tarafindan Endülüs'e atanan ilk vali olan Abdülaziz. b. Musa ile yerel idarecilerden Tudmir (Theodomiro) arasında 713 yllında imzalanan Tudmir Antlaşması'nı zikretmektedir. $\mathrm{Bu}$ bölümde Vizigotlar devrinde başkent olan Toledo yerine Müslümanların Kurtuba'yı merkez olarak tercih etme sebeplerine değinen yazar bu tercihte 
bölgenin mümbit topraklara sahip olmasının ve şehrin Akdeniz'e yakınlığının etkili olduğunu vurgulamaktadır. Endülüs'ün fethini takip eden yıllarda Müslümanların Avrupa içlerine yapmış oldukları seferler hakkında malumatın yer aldığ1 bu bölümde Endülüs Müslümanlarının Toulouse, Bordeaux, Burgundiya bölgesinde ilerleyişi ve 732 yllında Poitiers havalisinde cereyan eden savaşla bu ilerleyişin büyük ölçüde durması anlatılmaktadır. Tarihi olayların yanında o devirde sanatsal ve mimari yönden yaşanan dönüşümden bahseden Barry Vizigotlann Roma geleneklerini yarımadaya entegre ettiklerini bununla da kalmayıp emirlerde ve paralarda Latince kullandıklarını aktarmaktadır. Burada yarımadadaki Hristiyan mimarisinde biçimsel olarak Roma esintisi olduğu ve figürsel benzerliklerin bulunduğu vurgulanmaktadır. Kitabın bu bölümünde Müslümanların İber Yarımadası'nın büyük bir kısmını ele geçirmesiyle Hristiyanların Pelayo önderliğinde 718 y1lında Covadonga Savaşı'nda Müslümanları yenerek başlattıkları ve asırlarca sürdürdükleri Reconquista süreci hakkında malumat verilirken bahsedilen Covadonga adının asırlar sonra İspanya'da cumhuriyete karşı isyan eden Falanjistler tarafından bile benimsendiği belirtilmektedir. Yine bu bölümde Endülüs'ün Müslümanlarca fethi sonrasinda buraya yerleşen unsurlar ve yakın bölgelerdeki anlaşmazlıklardan bahseden Barry Endülüs'te Dimaşk’a bağlı valiler tarafından yönetildiği devirden I. Abdurrahman'ın Endülüs'e ulaşıp 756 yılında Endülüs Emevi Devleti'ni kurma sürecini aktarıp onun icra-i saltanat ylllarının sonuna kadar olan devirde yaşanan siyasi ve sosyo-kültürel olaylara da değinmektedir.

Eserin üçüncü bölümünde Endülüs Emevi Devleti'nin ilk hükümdarı olan I. Abdurrahman devri sonundan başlayarak III. Abdurrahman'ın Endülüs'te 929 y1lında hilafeti kurmasına kadar olan devrin tarihi, sosyal ve kültürel olaylar anlatılmaktadır. Siyasi olayların haricinde Michael B. Barry bu bölümde Endülüs'ün dünyanın önemli bir ilim merkezi haline gelme sürecini ve bu sürecin altında yatan saiklerin üzerinde durmuştur. Endülüs coğrafyası başlangıçtan itibaren buradan kutsal topraklara yapılan hac ziyaretleri ve Abbasi coğrafyasıyla etkileşim halinde olmasının sonucunda doğu-batı arasında din, bilim ve sanat gibi muhtelif sahalarda bilgi aktarımı sayesinde büyük bir ilim beldesi haline geldiği burada vurgulanmaktadır. Endülüs Emevi Hükümdarı II. Abdurrahman'ın bilim, sanat ve edebiyata düşkün olup sanatçı, âlim ve edipleri sarayında himaye ediyordu. $\mathrm{Bu}$ devirde Abbasi topraklarından meşhur musikişinas Ziryab'ın Endülüs'e gelmesiyle oradan birçok yenilik Endülüs topraklarına taşınmış oluyordu. Ayrıca bu dönemde İber Yarımadası'ndaki Hristiyan krallıklarla Avrupa'dan İber Yarımadası'na sefer düzenleyen Şarlman hakkında malumat verilip o yıllarda Avrupa'daki güç dengelerinden bahsedilmektedir. Endülüs'e dişarıdan gelen saldırılılardan bahseden yazar ayrıca iç karışıklıklar ve bu karışıklıkların sebepleri üzerine de tahliller yapmaktadır. Yine bu bölümün sonunda İber Yarımadası'nda Endülüs Emevi devrindeki Müslüman-Hristiyan çatışmalarının tarihi seyri hakkında malumat verilmektedir. 
Dördüncü bölümde Barry Endülüs Emevi Devleti hükümdarı III. Abdurrahman'1n iktidara gelmesinden Endülüs Emevi Halifeliği’nin ilga edilişine kadar olan devri siyasi, içtimai, dini ve kültürel yönleriyle mercek altına almaktadır. Bu bölümde yazar olayları siyasi, içtimai ve kültürel ayrımı yapmaksızın karma olarak anlatma yoluna gitmiştir. III. Abdurrahman’ın iktidara gelişi sonrasında İbn Hafsun gibi iç gaileleri bertaraf etmesi, Hristiyan İspanya’ya karşı başarılı askeri seferler düzenlemesiyle devlet büyük güç kazanmıştı. Öte taraftan Kuzey Afrika'da Fâtımîlerin Endülüs Emevilerine karşı siyasetler izlemeleri ve Şî̂ hilafetini kurduklarını ilan etmelerinden sonra III. Abdurrahman harekete geçip Endülüs Emevi Halifeliği'ni kurdu. Barry III. Abdurrahman'ın kendisini halife ilan etmesinde heretik olarak telakki ettiği Fâtımîleri kendisine karşı bir tehdit olarak alg1lamış olmasının etkili olduğunu vurgulamaktadır. III. Abdurrahman Kurtuba şehri yakınlarında inşa ettirdiği Medinetüzzehra Sarayı'nın temel özelliklerinden bahsedip burada yabancı elçilerin ağırlandığını dile getirmektedir. III. Abdurrahman devrinde her açıdan gelişen Endülüs Emevi Devleti gönenç devrini yaşamış ve başkent Kurtuba zenginlik ve ihtişam olarak Konstantinapolis ve Bağdat ile yarışacak seviyeye gelmişti. Endülüs Emevi Devleti'nin en haşmetli yılları olan III. Abdurrahman devrinde bilim ve teknikte Endülüs büyük bir gelişme kaydettiğini zikreden yazar hükümdarın eğitimli olmasının yanı sıra edebiyat ve bilim hamisi olduğunu vurgulamaktadır. Yazar, zamanla müreffeh bir ülke haline gelen Endülüs'te ekonomik zenginliğe bağlı olarak şair ve âlimlerin Medinetüzzehra'da hükümdarın sarayına akın ettiklerini böylelikle Endülüs'ün bilim ve kültürde büyük gelişme gösterdiğini söylemektedir. III. Abdurrahman devrinde gönenç devrini yaşayan Endülüs entelektüel bir şahsiyet olan II. Hakem'in devrinde de bilhassa kültürel sahada gücünü korumuştu. Bunun yanı sıra II. Hakem hâkimiyet yılları Kuzey Afrika'daki Müslüman devletler ve İber Yarımadası'ndaki Hristiyan krallıklarla mücadelelerin yaşandığı bir devirdir. Barry bu bölümde Endülüs Emevi Halifeliği'nin son zamanlarındaki siyasi olaylardan bahsettikten sonra 1031 yilında halifeliğin ortadan kaldırılmasıyla bölümü sonlandırır.

Yazar kitabının beşinci bölümünde Endülüs'te 1031 y1lından Murabitların bölgeye hâkim olduğu olduğu devre kadar olan olaylar ele almaktadır. Endülüs Emevi Devleti'nin inkıraza uğramasıyla bu topraklarda kurulan irili ufaklı Müslüman emirliklerinin hüküm sürdüğü Mülûkü't-Tavâif Devri'nde (1031-1090) her biri birbirinden bağımsız devletçiklerin mücadeleleri neticesinde yarımadada Müslüman nüfuzu zayıflamıştı. Barry bu devirde hüküm süren bu devletçiklerin yöneticileri, halk1 ve bu devirde oynadıkları rollerden bahsetmektedir. Burada vurgulanan hususlardan birisi de hangi etnik unsurların hangi bölgede daha güçlü olduğudur. Kitabın bu bölümünde siyasi olayların haricinde teknolojik gelişmelerden de bahsedilmektedir. Endülüs Müslümanlarının sulama sistemleri kullanımında Romalılar ve daha erken devirlerdeki tekniklerin de benimsendiğini bunun sonucunda Endülüs'ün mümbit topraklarında tarımsal ürün çeşitliliğinin arttığ1 zikredilmektedir. Yazar bu verimlilikte Endülüslülerin geliştirdikleri su tekerleğinin yanı sıra kanal ağları, su kemerleri ve barajların da etkili olduğundan 
bahsetmektedir. Son olarak bu bölümde 1085 y1lında Müslümanların elindeki en büyük şehirlerden olan Tuleytula'nın Hristiyanlar tarafından ele geçirilmesi ve Reconquista Hareketi'nin o zamana kadarki en müspet başarısı olan bu olayla İber Yarımadası'ndaki Müslüman-Hristiyan mücadelesinin nasıl değiştiği üzerine değerlendirmeler yapılmıştır.

Barry eserin altıncı bölümünde Kuzey Afrika merkezli Murabitlar ve Muvahhidler devletlerinin Endülüs'e hâkim olduğu devir hakkında birtakım malumat aktarılmaktadır. Berberi menşeli olan bu iki devletin kurucularının atalarının Müslüman olma süreci, yaşadıkları coğrafya ve yaşam tarzlarından bahseden yazar daha sonra Murabitlar'ın devlet kurma süreçleri ve Endülüs Müslümanlarının Hristiyan baskısı altında onlardan yardım istemeleri neticesinde Murabıtlar'ın yarımadaya geçişini anlatmaktadır. Yusuf b. Taşfin önderliğinde Murabitlar'ın bölgeye yaptığı askeri seferler ve en sonunda Endülüs coğrafyasını kendi devletlerine bağlama süreçlerinden bahseden yazar Murabıtlar'ın başkentini zaptederek devleti ortadan kaldıran Berberi menşeli Muvahhidlerin kuruluş ve Endülüs'e hâkim olmalarına değinmektedir. Murabıtlar ve Muvahhidler devri dini gelişmelerinden de bahseden Barry İslam dininin bu iki devletin kuruluşunda ve gelişiminde etkili olduğunu işaret etmektedir. Barry ayrıca Murabitlar ve Muvahhidler devrinde yetişmiş İbn Meymûn gibi önde gelen âlimlerden de bahsetmektedir. Bölümün sonunda Reconquista Hareketi'nin yarımada tarihinde en büyük zaferi olarak kabul edebileceğimiz 1212 y1lındaki Las Navas de Tolosa Savaşı'nda Muvahhidler'in birleşik Hristiyan-Haçlı ordusu karşısında aldığı ağır hezimet ve bunun neticesinde Endülüs'te Muvahhid hâkimiyetinin ortadan kalkış sürecinden bahsedilmektedir.

Yedinci bölüm Endülüs'e hâkim olmuş son Müslüman devlet olan Nasriler devrine ayrılmıştır. Gırnata ve çevresine egemen olan Nasriler yaklaşık 250 yıl yarımadada hükümranlıklarını sürdürmüşlerdi. Barry'nin görüşüne göre Nasriler düşman Hristiyan devletlerle anlaşma stratejisini güdüyorlardı. Nasriler'in İbnü'lAhmer devrinde Sierra Nevada Dağları'nın eteklerinde inşa ettikleri Elhamra Sarayı'nı Endülüs Emevileri devrinde inşa edilen Medinetüzzehra'ya benzeten yazar bu yapının zamanla Nasri hanedanının kalbi olduğunu vurgulamıştır. Siyasi olarak Hristiyanların baskısıyla muhataralı günler geçiren Nasriler'in bu devirde ilmi sahada önemli gelişmeler kaydettiğini belirten Barry I. Yusuf tarafindan 1349 yılında medrese inşa edildiği ve onun devrinde Gırnata'nın altın çağını yaşamaya başladığını ifade etmektedir. Son olarak 1469 yılında Kastilya Kraliçesi İzabella'nın Aragon Kralı Ferdinand ile izdivacı neticesinde bu iki devletin birleşmesi ve gözlerini Nasri topraklarına dikmesine değinen yazar 1492 yllında Endülüs'te İslam hâkimiyetinin ortadan kalkış sürecinden bahsetmektedir.

Kitabın sekizinci ve son bölümü İber Yarımadası'nda İslam egemenliğinin sona ermesinden sonra Hristiyan hâkimiyeti altında kalan Müslüman Moriskolar'in yaşadıkları zulüm ve Hristiyanlarca yarımadadan kovuluş süreci ele alınmaktadır. Zorla vaftiz edilen ve İslam dinini yaşamalarına engel olunan Moriskolar'ın 
yarımadadan kovulmalarından bahseden yazar göçe zorlanan Moriskolar'ın sayısı ve göç ettikleri coğrafyalar hakkında malumat vermektedir.

Eser yaklaşık sekiz asırlık İslam hâkimiyeti devrinde Endülüs'ün siyasi, içtimai, dini ve kültürel yönlerini ihtiva etmekte olup bu devrin kimi zaman kronolojik sıra olmaksızın ele alınması eserin olumsuz yönlerindendir. Yine siyasi, içtimai, dini ve kültürel meseleler tasnif edilemeksizin birlikte anlatılması okuyucunun konuyu anlamasını zorlaştırmaktadır. Bu eksikliklere rağmen eser, hacmi büyük olmamasına rağmen sekiz asırlık uzun bir devri farklı yönleriyle sinırlı da olsa ele alabilmesi bakımından önemlidir. Farklı olaylar arasında bağlantı kuran eser okuyucunun Endülüs tarihi ve medeniyeti tasavvuruna katkı sağlamaktadır. Hristiyan İspanya ile Müslüman Endülüs'te cereyan eden olayların yazar tarafindan zaman zaman birlikte değerlendirilmesi bu bağlantıya bir örnektir. Buna ilaveten Barry salt siyasi tarih üzerinden bir anlatı sunmak yerine devrin içtimai, dini ve kültürel meselelerine de vurgu yapmış olması yerinde bir yaklaşımdır. Sonuç olarak eser Endülüs tarihi üzerine çalışan ya da bu sahaya ilgi duyan araştırmacılar için bu eser Endülüs'te siyasi, içtimai, dini ve kültürel hayata dair malumat ihtiva etmesi bakımından önemli bir çalışmadır.

Enes Şanal*

* Doktora öğrencisi, İzmir Kâtip Celebi Üniversitesi, Sosyal Bilimler Enstitüsü, Tarih ABD, 35620, Balatçı, Çiğli-İzmir/Türkiye, enes.sanal91@gmail.com 